\title{
Effect of Mushroom Beta Glucan (MBG) on Immune and Haemocyte Response in Pacific White Shrimp (Litopenaeus vannamei)
}

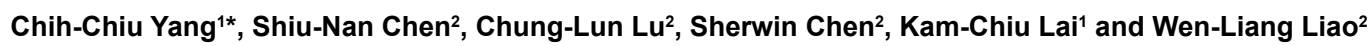

${ }^{1}$ College of Life Science, National Taiwan University, Taipei, Taiwan

${ }^{2}$ Institute of Fisheries Science, National Taiwan University, Taipei, Taiwan

\begin{abstract}
The total haemocyte count (THC), differential haemocyte count (DHC), respiratory bursts, and phenoloxidase (PO) activity were determined in the Pacific white shrimp Litopenaeus vannamei which administrated by feeding with diets containing mushroom beta glucan (MBG) at $0.05 \%$ and $0.1 \%$. Results showed that shrimp fed a diet containing $0.05 \%$ MGB had significantly increased THC and semi-granular cells ratio at 28 days. Intracellular superoxide anion (O2-) production were significantly increased at 14 days which shrimp fed a diet containing $0.05 \%$ MBG and PO activity were significantly increased at 14 days which shrimp fed a diet containing $0.1 \%$ MGB but equal with control at 28 days. In previously study, semi-granular cells were found as the primary immune activator with their high levels of granules, enzymes and proteins. In this study, the effectively enhance immune responses and compare to high induced semi-granular cells in Pacific white shrimps concluded that MBG is an effective and powerful immunostimulants for shrimp. For application in aquaculture, MBG administration through dietary administration is also a convenient and useful practical technique in the future.
\end{abstract}

Keywords: Litopenaeus vannamei; Mushroom beta glucan; Hyaline cell; Semigranual cell; Granual cell

\section{Introduction}

Pacific White shrimp Litopenaeus vannamei is the primary penaeid shrimps currently being cultured in Central and South America, as well as Pacific Rim countries. For more than two decades, shrimp farming has suffered viral disease problems like Taura syndrome virus (TSV) and Pacific white spot syndrome virus (WSSV) $[1,2]$, as well as vibriosis due to Vibrio alginolyticus and V. harveyi [3]. Disease outbreaks are often a result of a deteriorated environment which is associated with intensification of cultivation, and with increases in the proportion of potentially pathogenic species in the Vibrio population of cultured pond waters [4]. Therefore, the immune ability of shrimp and their susceptibility to pathogens are of primary concern when they are subjected to environmental stressors. Penaeid shrimp like other invertebrates rely on an innate immune system for protection against pathogens [5]. Once microorganisms or other foreign particles invade the haemocoel of the host, they encounter a complex system of innate defence mechanisms involving cellular and humoral responses [6]. These include phagocytosis, nodulation, encapsulation, synthesis of antimicrobial peptides, blood coagulation, release of stress-responsive proteins, and the prophenoloxidase (proPO) activating system that leads to melanization [7]. The total haemocyte count (THC), phenol oxidase (PO) activity, respiratory burst (release of superoxide anion), superoxide dismutase (SOD) activity, phagocytic activity and bacterial clearance efficiency are commonly used as indicators for evaluating a host's immunity and health status $[8,9]$.

The immune stimulatory effects of glucan, chitosan, and other polysaccharides have been widely studied in fish and crustaceans [10]. The shrimp's immune system is activated by pattern recognition proteins including lipopolysaccharide, $\beta$-glucan and peptidoglycan binding proteins [11]. Once these proteins are bound to their specific targets, they activate haemocytes to release their contents and trigger different biochemical mechanisms [12]. Immunostimulants have been found to increase the immune responses in several shrimp species by promoting phagocytosis, bactericidal activity, proPO activity, and respiratory bursts, and enhancing resistance against pathogens [13]. $\beta$-glucan is polysaccharides of $\mathrm{D}$-glucose monomers linked by $\beta$-glycosidic bonds. This structure occur most commonly in algals, the bran of cereal grains, the cell wall of baker's yeast, certain fungi, mushrooms and bacteria. The $\beta$-glucan isolated from the mushrooms are poly-glucose of $\beta-1,3$ or $\beta-1,3$ and $\beta-1,6$ cross-linked compounds [14]. Approximately $50 \%$ of the fungal species are able to release water-soluble $\beta$-glucan. In particular, $\beta$-glucans with $\beta-1,3$ as the primary chain and $\beta-1,6$ as the branched chains demonstrate immune-regulatory effects. Different fungal species contain $\beta$-glucans with varying proportions of the main and branched chains. In the recent years, there have been many studies published in the field of aquaculture relating to injection, immersion and supplementation of $\beta$-glucans in the feeds to enhance nonspecific immunity of the cultured animals. Chen and Ainsworth noted that injection of $\beta$-glucan is effective against Edwardsiella ictaluri in catfish Lctalurus punctatus [15]. Also, $\beta$-glucan enhanced the cytotoxic activities of macrophages, lymphocytes and natural killer cells in fish immune system [16,17] and promoted proPO in the lymphatic fluids of crayfish and horseshoe crabs, leading to a fortified bactericidal effect and phagocytosis, in addition to promotion of haemolymph coagulation $[18,19]$. Immersion of 0.5 and $1.0 \mathrm{mg} / \mathrm{ml} \beta$-glucan improved Penaeus monodon in enhances the shrimps' immunity against Vibrio vulnificus [20]. Furthermore, $\beta$-glucan was examined in Pacific white shrimps that can enhance these shrimps' immunity against WSSV [21].

In this paper, diets containing mushroom $\beta$-glucan (MBG)

*Corresponding author: Chih-Chiu Yang, College of Life Science, National Taiwan University, Taipei, Taiwan, Tel: 886233662797; E-mail: snchen@ntu.edu.tw

Received July 03, 2014; Accepted September 27, 2014; Published October 01 2014

Citation: Yang CC, Chen SN, Lu CL, Chen S, Lai KC, et al. (2014) Effect of Mushroom Beta Glucan (MBG) on Immune and Haemocyte Response in Pacific White Shrimp (Litopenaeus vannamei). J Aquac Res Development 5: 275 doi:10.4172/2155-9546.1000275

Copyright: ( 2014 Yang CC, et al. This is an open-access article distributed unde the terms of the Creative Commons Attribution License, which permits unrestricted use, distribution, and reproduction in any medium, provided the original author and source are credited. 
(M.W.=559.63 to $6.65 \mathrm{kDa}$ ) was administered among L. vannamei to study the its impact on THC, differential haemocyte count (DHC), intracellular superoxide anion $\left(\mathrm{O}_{2}^{-}\right)$production and $\mathrm{PO}$ activity.

\section{Materials and Methods}

\section{Animal}

L. vannamei were obtained from National Taiwan Ocean University (Keelung, Taiwan). Upon arrival, shrimps were acclimated to laboratory conditions for one week in a glass tank $(200 \mathrm{~L})$ and fed a basal diet (without MBG). At the beginning of the experiment, nine aquaria (200 L) were each stocked with 50 shrimps with an average initial weight of $13 \pm 1 \mathrm{~g}$. Three groups of shrimps were fed with experimental diet. Continuous aeration was maintained for each aquarium and $75 \%$ of the water in each aquarium was changed weekly to remove impurities and maintain optimal water quality. Dissolved oxygen concentration was maintained $\geqq 4 \mathrm{mg} / \mathrm{L}$ throughout the experimental period. Water temperature ranged from $27-29^{\circ} \mathrm{C}$, as $\mathrm{pH}$ ranged from 7.3-8.3 and salinity ranged from $30-32 \%$. A photoperiod of 12 hours light, 12 hours dark (08.00-20.00 h) was implemented. Groups of shrimps were fed their respective diet at a rate of $8 \%$ of body weight each day. This daily ration was divided into two equal feedings at 08.30 and $17.30 \mathrm{~h}$. The duration of the study was four weeks.

\section{Preparation of experimental diet}

The experimental Mushroom Beta Glucan (MBG) extracted from Ganoderma lucidum and Coriolus versicolor was supplied by Super Beta Glucan Inc. (Irvine, California, USA) [17]. Based on the recommended nutrient requirements of $L$. vannamei [22], a basal diet was formulated without immunostimulants (Table 1 ), and $0.05 \%$ and $0.1 \%$ of MBG was added and mixed to the shrimp feeds as the experimental diet. All dietary ingredients were ground into a fine powder through a 149 $\mu \mathrm{m}$ mesh sieve and mixed thoroughly with fish oil and cold water. The mixture was then passed through an extruder with a $1.5 \mathrm{~mm}$ die to produce spaghetti-like strings. After drying, the diets were cut into pellets and stored at $-20^{\circ} \mathrm{C}$ for experiment.

\section{Experimental design}

Haemolymph extraction and haemocyte identification: At 0,14 and 28 days of the feeding trial, five shrimps were randomly selected from each aquarium. Haemolymph was withdrawn from the ventral sinus of each shrimp with a 1-mL sterile syringe (26-gauge) containing $0.9 \mathrm{ml}$ of an anticoagulant solution $(0.45 \mathrm{M} \mathrm{NaCl}, 0.1 \mathrm{M}$

\begin{tabular}{|c|c|}
\hline Ingredients & Percentage \\
\hline Fish meal & 25 \\
\hline Shrimp head meal & 5 \\
\hline Peanut meal & 14 \\
\hline Squid visceral meal & 5 \\
\hline Soybean meal & 18 \\
\hline Fish oil & 1 \\
\hline Soy lecithin & 2 \\
\hline Wheat flour & 27.58 \\
\hline Choline chloride $(50 \%)$ & 0.30 \\
\hline Ca( H $_{2}$ PO $\left._{4}\right)_{2}$ & 0.37 \\
\hline Vitamin permix & 0.5 \\
\hline Mineral permix & 1 \\
\hline Cellulose & 0.25 \\
\hline
\end{tabular}

MBG replaced from cellulose, $\mathrm{T} 1$ group contains $0.05 \%$ of MBG; T2 group contains $0.1 \%$ of $M B G$

Table 1: Composition of the basal diets (as percentage dry weight). glucose, $10 \mathrm{~mm}$ EDTA, $30 \mathrm{~mm}$ Sodium citrate, $26 \mathrm{~mm}$ citrate acid, $\mathrm{pH}$ 7.3, osmolality $900 \mathrm{mOsm} \mathrm{kg}{ }^{-1}$ ), a modification from the solution described by Söderhäll and Smith [23]. A drop of the anticoagulantehaemolymph mixture $(100 \mu \mathrm{L})$ was placed on a haemocytometer to measure hyaline cell, granular cell and semi-granular cell), and the total haemocyte count (THC) and different haemocyte count (DHC) were determined using an inverted phase-contrast microscope (Olympus, IMT-20, Japan). The remainder of the haemolymph mixture was used for subsequent tests.

Intracellular superoxide anion $\left(\mathrm{O}_{2}^{-}\right)$production assay: Intracellular superoxide anion $\left(\mathrm{O}_{2}^{-}\right)$production of the haemocytes was quantified using the reduction of nitrobluetetrazolium (NBT) to formazan as a measure of superoxide anion production [20]. The collected haemolymph was diluted with 4 volumes of anticoagulant, and then centrifuged at $700 \times \mathrm{g}$ for $10 \mathrm{~min}$ at $4^{\circ} \mathrm{C}$. The resultant haemocyte pellet was then resuspended to $10^{6}$ cells $\mathrm{ml}^{-1}$ in a modified complete Hank's balanced salt solution (MCHBSS) containing $10 \mathrm{mM} \mathrm{CaCl}_{2}, 3$ $\mathrm{mM} \mathrm{MgCl}_{2}, 5 \mathrm{mM} \mathrm{MgSO}_{4}$ and $24 \mathrm{mg} \mathrm{ml}^{-1} \mathrm{HBSS}$ (Sigma). Haemocyte suspension $(100 \mu \mathrm{L})$ was added to flat-bottomed 96 well microtitre plates $\left(10^{5}\right.$ haemocytes well $\left.{ }^{-1}\right)$ and cytocentrifuged at $700 \mathrm{xg}$ for 20 min at $4^{\circ} \mathrm{C}$. After removing the supernatant, $\mathrm{O}_{2}^{-}$production of the haemocytes was quantified by a zymosan $\left(2 \mathrm{mg} \mathrm{ml}^{-1}\right.$, Sigma) induced well which compare to non-induced well (MCHBSS added). NBT (100 $\mu \mathrm{L}, 0.3 \%$ in MCHBSS) was then added to the haemocytes and more incubated for $30 \mathrm{~min}$ at $37^{\circ} \mathrm{C}$. The staining reaction was terminated by removing the NBT solution and adding absolute methanol. After three washes with $70 \%$ methanol, haemocytes were air-dried. $120 \mu \mathrm{L}$ $2 \mathrm{M} \mathrm{KOH}$ and $140 \mu \mathrm{L}$ dimethyl sulfoxide were added to dissolve the cytoplasmic formazan. Optical densities of the dissolved cytoplasmic formazan were measured at $630 \mathrm{~nm}$ with a precision microplate reader. Ratio of $\mathrm{OD}_{630}$ of the zymosan stimulated haemocytes to the $\mathrm{OD}_{630}$ of the control haemocytes was used as an index for comparing the effect of different level of MBG on $\mathrm{O}_{2}$ :

PO activity assay: Phenoloxidase (PO) activity was measured spectrophotometrically by recording the formation of dopachrome produced from L-3,4-dihydroxyphenylalanine (L-DOPA) as previously described by Liu et al. [24,25]. Optical density at $490 \mathrm{~nm}$ of the shrimp's PO activity was measured using a spectrophotometer and expressed as dopachrome formation per $50 \mu \mathrm{L}$ of haemolymph.

\section{Statistical Analysis}

Data were analyzed by one-way ANOVA from which multiple comparisons among the different means detected were made with Duncan's new multiple range tests. Statistical significance was determined by setting the aggregate type I error at $1 \%(\mathrm{P}<0.01)$ for each set of comparison.

\section{Result}

\section{Total haemocyte count (THC)}

Shrimps fed with diets containing MBG at $0.1 \%$ concentrations for 14 day exhibited higher THC than the control group significantly. Statistically significant higher THC was also observed in the shrimps receiving feeds containing 0.05 and $0.1 \%$ MBG for 28 days than the control group $(\mathrm{P}<0.05)$ (Figure 1$)$.

\section{Differential haemocyte count (DHC)}

Shrimps fed with diets containing 0.05\% MBG for 14 days exhibited statistically significant lower granular cell counts than the 


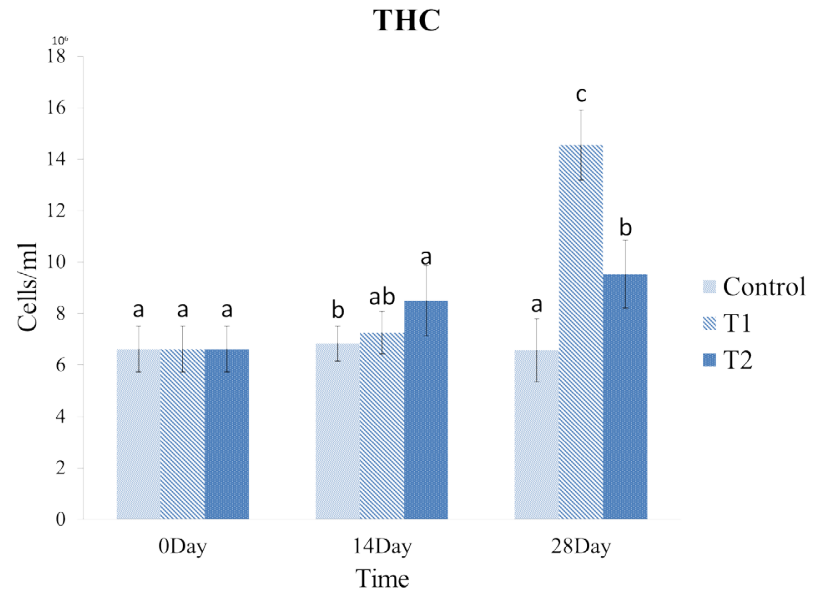

Figure 1: THC of Pacific white shrimp (L. vannamei) fed with diets contain.

\begin{tabular}{|l|l|l|l|l|}
\hline Days & Population & Control & $\mathbf{0 . 0 5 \%}$ & $\mathbf{0 . 1} \%$ \\
\hline 0 & & $11.05 \% \pm 2.50 \%$ & $11.15 \% \pm 2.20 \%$ & $11.35 \% \pm 2.29 \%$ \\
\hline 14 & Hyaline cell & $13.92 \% \pm 2.85 \%$ & $13.20 \% \pm 2.94 \%$ & $9.92 \% \pm 2.28 \%$ \\
\hline 28 & & $11.38 \% \pm 2.83 \%^{\mathrm{a}}$ & $6.37 \% \pm 2.22 \%^{\mathrm{b}}$ & $9.95 \% \pm 1.77 \%^{\mathrm{a}}$ \\
\hline 0 & & $28.05 \% \pm 6.98 \%$ & $28.05 \% \pm 6.98 \%$ & $28.05 \% \pm 6.98 \%$ \\
\hline 14 & Granular cell & $31.26 \% \pm 4.33 \%^{\mathrm{a}}$ & $26.03 \% \pm 3.95 \%^{\mathrm{b}}$ & $30.62 \% \pm 4.18 \%^{\mathrm{a}}$ \\
\hline 28 & & $13.75 \% \pm 4.24 \%^{\mathrm{a}}$ & $10.32 \% \pm 3.26 \%^{\mathrm{b}}$ & $11.49 \% \pm 2.74 \%^{\mathrm{ab}}$ \\
\hline 0 & & $60.90 \% \pm 7.04 \%^{\mathrm{b}}$ & $60.90 \% \pm 7.04 \%$ & $60.90 \% \pm 7.04 \%$ \\
\hline 14 & Semi-Granular cell & $54.82 \% \pm 4.18 \%^{\mathrm{b}}$ & $60.77 \% \pm 2.64 \%^{\mathrm{a}}$ & $59.46 \% \pm 4.68 \%$ \\
$\mathrm{ab}$
\end{tabular}

Values are means S.D, $n=5$

a,b,c: Values with different superscripts in each column are significantly different $(P<0.01)$

Table 2: Different haemocyte count (DHC) of Pacific white shrimp fed diets with different level of Mushroom beta-glucan (MBG) for 28 days.

groups fed with $0.1 \%$ and control diet, respectively $(\mathrm{p}<0.05)$, but a statistically significant higher semi-granular cell count than the group fed with control diet $(\mathrm{p}<0.05)$. At 28 days, a significant lower hyaline and granular cell count was observed in the group receiving feeds containing $0.05 \%$ MBG. In addition, the MBG treated groups for 28 days showed the higher semi-granular cell count than the group fed with control diet $(\mathrm{p}<0.05)$ (Table 2$)$.

\section{Intercellular superoxide anion $\left(\mathrm{O}_{2}^{-}\right)$production}

Results obtained from the observation of intercellular superoxide anion production in the shrimp fed with various concentrations of MBG were presented in Figure 2. Both the groups fed with diets containing MBG for 14 days exhibited statistically significant higher activities than the control group $(\mathrm{P}<0.05), 0.05 \% \mathrm{MBG}$ showed the highest activity and then was $0.1 \%$ MBG. At 28 days, $0.05 \%$ MBG and $0.1 \%$ MBG treated group showed statistically significant higher activities than the control group, but no statistical difference existed between these two groups $(\mathrm{P}<0.05)$.

\section{PO activity}

Results obtained from the observation of PO activity in the groups fed with two concentrations of MBG were presented in Figure 3. PO activity of the group fed with MBG for 14 days exhibited statistically significant higher activities than the control group $(\mathrm{P}<0.05)$ and showed a dosage dependent. At 28 days, there was no statistically significant differences in experimental treated groups $(\mathrm{P}>0.05)$.

\section{Discussion}

Beta glucans derived from microorganisms have been used to enhance innate immunity and improve resistance against pathogens in experimental aquatic animals [26,27]. In modern aquaculture applications, beta glucan derived from the mushrooms has demonstrated its efficacy in enhancing innate immunity and pathogen resistance in cultured shrimps and mollusks successfully [28-31].

Beta glucan not only plays an important role in the nonspecific immune system of the Pacific white shrimps, but it is also associated with shrimp haemocyte's pattern recognition, phagocytosis, reactive oxygen species formation, prophenoloxidase activating system, encapsulation, nodule formation, and release of antimicrobial peptides and lysozymes $[6,7,24]$. With elevated haemolymph THC, there is an increased number of immune cells to combat infectious sources and subsequently, reduces mortality. Among all haemocytes types in Pacific white shrimps, hyaline cells are the smallest shape with the highest nucleus-to-cytoplasm ratio and minimal granules to execute

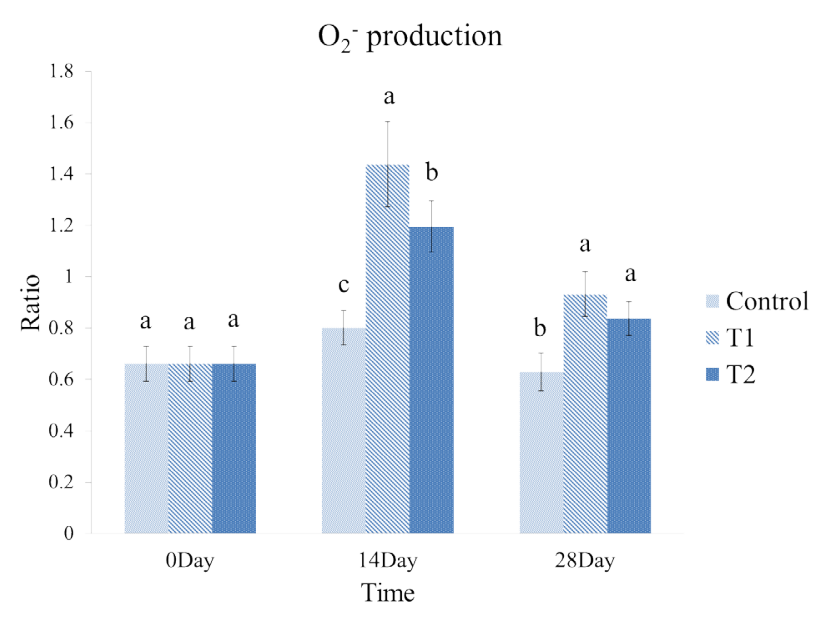

Figure 2: Intracellular superoxide anion (O2-) production of Pac.

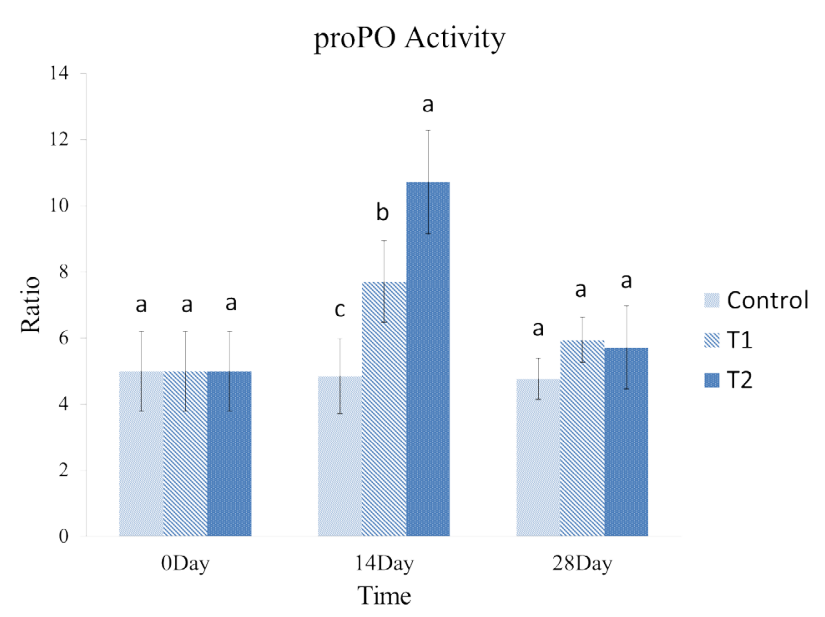

Figure 3: ProPO activity of Pacific white shrimp (L. vannamei). 
Citation: Yang CC, Chen SN, Lu CL, Chen S, Lai KC, et al. (2014) Effect of Mushroom Beta Glucan (MBG) on Immune and Haemocyte Response in Pacific White Shrimp (Litopenaeus vannamei). J Aquac Res Development 5: 275 doi:10.4172/2155-9546.1000275

Page 4 of 5

phagocytosis. The size of semi-granular cells and their nucleus-tocytoplasm ratio is in between that of the granular cells and hyaline cells. Additionally, semi-granular cells contain fewer granules and more cytoplasm and are capable of complement-dependent cytotoxicity, prophenoloxidase (proPO) activation and weak phagocytosis. Granular cells have the largest volume, smallest nucleus and largest granules of the three types of cells $[6,7,23,32]$. Of the three, semi-granular cells are the most unstable and sensitive haemocytes, which frequently degranulate after being stimulated by foreign particles such as LPS and $\beta$-glucan, resulting in cell breakdown if more seriously [7,33,34].

Because each of the three types of haemocytes has its niche of function, the varying proportions of the three cell types at a given time indicate a particular immune function in progress. After administration of MBG for 14 days, the total numbers of all three haemocytes were higher in treated groups than the control group. After 28 days, $0.05 \%$ treated group showed the highest total blood cell counts. However, after 14 days, the proportions of haemocytes did not change, indicating an enhancement of immune function from baseline without bias towards a specific function. At 28 days, $0.05 \%$ treated group showed an increase in the proportion of semi-granular cells, as these cells are the most sensitive and reactive of the three haemocytes [33]. In another words, semi-granular cells act as the primary immune activator of the Pacific white shrimps with their high levels of granules, enzymes and proteins. Therefore, an increase in the proportions of semi-granular cells can effectively enhance immune response in Pacific white shrimps.

In the present study, both haemocyte intercellular superoxide anion production and PO activity increased after MBG treated at 14 days. After 28 days, these factors were reduced and similar to the control group. On the other hand, THC and DHC levels were significantly different between the treatment and control groups. We speculate that this difference is a result of using immune-naive Pacific white shrimps without previous stimulation by infectious sources as our experimental hosts. Consequently, although immune markers were not elevated, THC and DHC levels showed a significant increase after supplementation of MBG in the feeds, resulting in an increased immune response to infections $[13,16,18,21]$.

Using G. lucidum and C. versicolor as the sources of origin, mushroom beta glucan was extracted and analyzed, followed by employment of HPLC to determine the specific molecular weight [17]. Supplementation to feeds and determination of immune markers were subsequently performed. This study showed that MBG enhances the innate immune response with surrogate markers of THC, DHC, intercellular superoxide anion production, and PO activity of the Pacific white shrimps. As the use of natural immunomodulators is getting more attention, we suggest that MBG is an effective and powerful Immunostimulants for shrimp aquaculture and can be useful in practical applications during the post larvae stage.

\section{References}

1. Lo CF, Chang YS, Peng SE, Kou GH (2003) Major viral diseases of Penaeus monodon in Taiwan. J Fisheries Soc Taiwan 30: 1-13.

2. Yu Cl, Song YL (2000) Outbreaks of Taura syndrome in Pacific white shrimp Penaeus vannamei cultured in Taiwan. Fish Pathol 35: 21-4.

3. Liu CH, Cheng W, Hsu JP, Chen JC (2004) Vibrio alginolyticus infection in the white shrimp Litopenaeus vannamei confirmed by polymerase chain reaction and 16S rDNA sequencing. Dis Aquat Organ 61: 169-174.

4. Lavilla-Pitogo CR, Leano EM, Paner MG (1998) Mortalities of pond-cultured juvenile shrimp, Penaeus monodon, associated with dominance of luminescent vibrios in the rearing environment. Aquaculture 164: 337-349.

5. Anderson DP (1992) Immunostimulants, adjuvants, and vaccine carriers in fish:
Applications to aquaculture. Ann Rev Fish Diseases 2: 281-307.

6. Takahashi Y, Itami T, Kondo M (1995) Immunodefense system of crustacea Fish Pathol. 30:141-50

7. Jiravanichpaisal P, Lee BL, Söderhäll K (2006) Cell-mediated immunity in arthropods: hematopoiesis, coagulation, melanization and opsonization. Immunobiology 211: 213-236.

8. Le Moullac G, Haffner P (2000) Environmental factors affecting immune responses in Crustacea. Aquaculture 191: 121-131.

9. Rodriguez J, Le Moullac G (2000) State of the art of immunological tools and health control of penaeid shrimp. Aquaculture 191: 109-119.

10. Sakai M (1999) Current research status of fish immunostimulants. Aquaculture 172: 63-92.

11. Cheng W, Liu CH, Tsai $\mathrm{CH}$, Chen JC (2005) Molecular cloning and characterisation of a pattern recognition molecule, lipopolysaccharide- and beta-1,3-glucan binding protein (LGBP) from the white shrimp Litopenaeus vannamei. Fish Shellfish Immunol 18: 297-310.

12. Wang XW, Wang JX (2013) Pattern recognition receptors acting in innate immune system of shrimp against pathogen infections. Fish Shellfish Immuno 34: 981-989.

13. Chang CF, Chen HY, Su MS, Liao IC (2000) Immunomodulation by dietary beta-1, 3-glucan in the brooders of the black tiger shrimp Penaeus monodon. Fish Shellfish Immunol 10: 505-514.

14. Yano T, Mangindaan REP, Matsuyama $\mathrm{H}$ (1989) Enhancement of the Resistance of Carp Cyprinus-Carpio to Experimental Edwardsiella-Tarda Infection, by Some Beta-1,3-Glucans. Nippon Suisan Gakk 55: 1815-1819.

15. Chen D, Ainsworth AJ (1992) Glucan Administration Potentiates Immune Defense-Mechanisms of Channel Catfish, Ictalurus-Punctatus Rafinesque. J fish diseases 15: 295-304

16. Engstad RE, Robertsen B, Frivold E (1992) Yeast glucan induces increase in lysozyme and complement-mediated haemolytic activity in Atlantic salmon blood. Fish Shellfish Immunol 2: 287-297.

17. Chang CS, Huang SL, Chen S, Chen SN (2013) Innate immune responses and efficacy of using mushroom beta-glucan mixture (MBG) on orange-spotted grouper, Epinephelus coioides, aquaculture. Fish Shellfish Immunol 35: 115125

18. Söderhäll K (1981) Fungal cell wall beta-1,3-glucans induce clotting and phenoloxidase attachment to foreign surfaces of crayfish hemocyte lysate. Dev Comp Immunol 5: 565-573.

19. Cerenius L, Söderhäll K (2011) Coagulation in invertebrates. J Innate Immun 3: 3-8.

20. Song YL, Hsieh YT (1994) Immunostimulation of tiger shrimp (Penaeus monodon) hemocytes for generation of microbicidal substances: analysis of reactive oxygen species. Dev Comp Immunol 18: 201-209.

21. Bai N, Gu M, Zhang W, Xu W, Mai K (2014) Effects of ß-glucan derivatives on the immunity of white shrimp Litopenaeus vannamei and its resistance against white spot syndrome virus infection. Aquaculture 426-427: 66-83.

22. Shiau SY (1998) Nutrient requirements of penaeid shrimps. Aquaculture 164 $77-93$.

23. Söderhäll K, Smith VJ (1983) Separation of the haemocyte population of Carcinus maenas and other marine decapods, and prophenoloxidase distribution. Dev Comp Immunol 7: 229-239.

24. Hemández-López J, Gollas-Galván T, Vargas-Albores F (1996) Activation of the Prophenoloxidase System of the Brown Shrimp (Penaeus californiensis Holmes). Comp Biochem Physiol 113: 61-66.

25. Liu CH, Chen JC (2004) Effect of ammonia on the immune response of white shrimp Litopenaeus vannamei and its susceptibility to Vibrio alginolyticus. Fish Shellfish Immunol 16: 321-334.

26. El-Boshy ME, El-Ashram AM, AbdelHamid FM, Gadalla HA (2010) Immunomodulatory effect of dietary Saccharomyces cerevisiae, beta-glucan and laminaran in mercuric chloride treated Nile tilapia (Oreochromis niloticus) and experimentally infected with Aeromonas hydrophila. Fish Shellfish Immunol 28: 802-808.

27. Harikrishnan R, Balasundaram C, Heo MS (2011) Diet enriched with mushroom 
Citation: Yang CC, Chen SN, Lu CL, Chen S, Lai KC, et al. (2014) Effect of Mushroom Beta Glucan (MBG) on Immune and Haemocyte Response in Pacific White Shrimp (Litopenaeus vannamei). J Aquac Res Development 5: 275 doi:10.4172/2155-9546.1000275

Phellinus linteus extract enhances the growth, innate immune response, and disease resistance of kelp grouper, Epinephelus bruneus against vibriosis. Fish Shellfish Immunol 30: 128-134.

28. Encarnacion AB, Fagutao F, Hirayama J, Terayama M, Hirono I, et al. (2011) Edible mushroom (Flammulina velutipes) extract inhibits melanosis in Kuruma shrimp (Marsupenaeus japonicus). J Food Sci 76: C52-58.

29. Gu M, Ma HM, Mai KS, Zhang WB, Bai N, et al. (2011) Effects of dietary beta-glucan, mannan oligosaccharide and their combinations on growth performance, immunity and resistance against Vibrio splendidus of sea cucumber, Apostichopus japonicus. Fish Shellfish Immunol 31: 303-309.

30. Yeh SP, Hsia LF, Chiu CS, Chiu ST, Liu CH (2011) A smaller particle size improved the oral bioavailability of monkey head mushroom, Hericium erinaceum, powder resulting in enhancement of the immune response and disease resistance of white shrimp, Litopenaeus vannamei. Fish Shellfish Immunol 30: 1323-1330.

31. Zhu F, Zhang $X$ (2012) Protection of shrimp against white spot syndrome virus (WSSV) with $\hat{i}^{2}-1,3-D-g l u c a n-e n c a p s u l a t e d ~ v p 28-s i R N A$ particles. Mar Biotechnol (NY) 14: 63-68.

32. Guzman MA, Ochoa JL, Vargas-Albores F (1993) Haemolytic activity in the brown shrimp (Penaeus californiensis Holmes) haemolymph. Comp Biochem Physiol A Comp Physiol 106: 271-275.

33. Cerenius L, Jiravanichpaisal P, Liu HP, Söderhill I (2010) Crustacean immunity. Adv Exp Med Biol 708: 239-259.

34. Sritunyalucksana K, Söderhäll K (2000) The proPO and clotting system in crustaceans. Aquaculture 191: 53-69. 